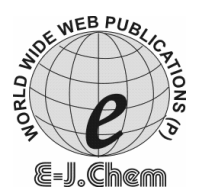

http://www.e-journals.net
ISSN: 0973-4945; CODEN ECJHAO

E-Journal of Chemistry

Vol. 5, No.4, pp. 723-735, October 2008

\title{
Vibrational and Quantum Chemical Study of Triphenylantimony(V)-o-salicylate
}

\author{
TANVEER HASAN ${ }^{\S}$, P. K.SINGH ${ }^{\S}$, P.RAJ $^{\#}$, \\ K.SINGHAL ${ }^{\#}$ and NEERAJ MISRA ${ }^{{ }^{*}}$ \\ ${ }^{\S}$ Department of Physics, "Department of Chemistry, \\ Lucknow University, Lucknow-226007, India. \\ neerajmisra@hotmail.com; Phone: 91-0522-2335914
}

Received 20 November 2007; Accepted 15 January 2008

\begin{abstract}
A complete normal coordinate analysis was performed by two different methods: a classical Wilson G-F matrix method and the semi-empirical molecular orbital PM3 method, for a five coordinate non rigid triphenyl antimony diester $\mathrm{SbPh}_{3}\left(\mathrm{O}_{2} \mathrm{CR}\right)_{2}\left[\mathrm{R}=\mathrm{C}_{6} \mathrm{H}_{4} \mathrm{OH}-o\right]$, known to be a bioactive molecule. The study of vibrational spectra suggested that the title compound might have secondary bonding interaction between the central antimony atom and the carbonyl oxygen atoms. The atomic charge distribution, geometry optimization and thermochemistry, were also calculated by PM3 method, which help in finding the potential sites of the title compound.
\end{abstract}

Keywords: FT-IR spectra, Triphenylantimony(V)-o-Salicylate, Normal coordinate analysis, Semiempirical, Organometallic compounds, Thermochemistry.

\section{Introduction}

Organic derivatives of group (15) elements have attracted attention not only because of the structural aspects but also from biological point of view. These compounds show the bactericidal and fungicidal effects ${ }^{1}$, which have got wonderful applications in textile industry $^{2,3}$. Recent publications reveal a renewed interest in the antifungal, antibacterial and cytotoxic studies of organoantimony carboxylate and salicylates derivatives. The enhanced antitumour activity of diphenyl antimony(III) thiolates, both in vitro and in vivo, led to the development of other types of organoantimony(III) and antimony(V) derivatives. In phenylantimony $(\mathrm{V})$ amines and dicarboxylates displayed some inhibition against a variety of human tumor cell lines. Recent studies show that organoantimony salicylates have considerable potential to be an antitumour active compound and therefore they are required to be treated in much extensive and detailed vibrational study in order to have better insight of these compounds. The title compound has been taken from the work of Barucki et $a l^{4}$ for its vibrational and thermodynamical study. 
In this manuscript, the experimental FT-IR is compared with theoretical frequencies obtained by normal coordinate analysis using two different methods: a classical mechanics method using Wilson GF matrix method and the semi-empirical quantum chemical molecular orbital PM3 method ${ }^{5}$. Thus the evaluation of the advantages of both methods is useful for obtaining a reliable assignment of the vibrational spectra. Assignments are thus proposed for observed frequencies corresponding to backbone \& mixed modes, side chain modes and ring modes on the basis of the potential energy distribution (PED).

The author's interest in the vibrational dynamics as well as quantum chemical study of the title compound triphenylantimony(V)-o-salicylate, $\mathrm{SbPh}_{3}\left[\mathrm{O}_{2} \mathrm{CC}_{6} \mathrm{H}_{4}(\mathrm{OH})-o\right]_{2}$ was stimulated by the fact that the title compound exhibited the antifungal, antibacterial and antitumour activities ${ }^{1}$ up to considerable amount.

In this work, the theoretical study for the title compound is presented, which also includes its geometrical parameters, atomic charge distribution and thermochemistry calculated by semi empirical PM3 method, using Mopac 2007 software $^{6}$. Recent studies show that the organoantimony salicylates are significantly potent against MCF-7 cell line ${ }^{7}$, but the vibrational study and the quantum chemical calculations of the title compound have not been investigated yet, and are being probed in the present work.

\section{Theory}

The Wilson's G-F Matrix method ${ }^{8}$ with Urey Bradley ${ }^{11}$ force field has been used to evaluate the normal modes. These are given by the eigen values $\lambda$ of the secular Equation.

$$
\begin{aligned}
\text { GFL } & =\lambda \mathrm{L}, \\
\text { as } \lambda & =4 \pi^{2} c^{2} v^{2}
\end{aligned}
$$

The potential is represented as

$$
\begin{aligned}
& V=\sum_{j k} K_{j k}^{\prime} r_{j k}\left(\Delta r_{j k}\right)+\frac{1}{2} K_{j k}\left(\Delta r_{j k}\right)^{2}+\sum_{i j k} H_{i j k}^{\prime} r_{i j} r_{j k}\left(\Delta \phi_{i j k}\right)+\frac{1}{2} H_{i j k} r_{i j} r_{j k}\left(\Delta \phi_{i j k}\right)^{2} \\
& +\sum_{i j k} F_{i k}^{\prime} q_{i k}\left(\Delta q_{i k}\right)+\frac{1}{2} F_{i k}\left(\Delta q_{i k}\right)^{2}+\sum_{i} K_{j}^{w}\left(\Delta w_{j}\right)^{2}+\sum_{j} K_{j}^{t}\left(\Delta t_{j}\right)^{2}
\end{aligned}
$$

where, $\Delta r_{j k}, \Delta \phi_{i j k}, \Delta w_{j}$ and $\Delta t_{j}$ are the internal coordinate changes corresponding to bond stretch, angle bend, out of plane deformation and torsion respectively. The potential energy distribution in the $j^{\text {th }}$ internal coordinate for the $i^{\text {th }}$ normal mode is given by

$$
(\mathrm{PED})=\frac{\mathrm{L}_{\mathrm{ji}}^{*} \mathrm{~L}_{\mathrm{ji}} \mathrm{F}_{\mathrm{ji}}}{\lambda_{\mathrm{i}}}
$$

\section{Experimental}

$\mathrm{X}$-ray data of the compound Triphenylantimony(V)-o-salicylate $\mathrm{SbPh}_{3}\left[\mathrm{O}_{2} \mathrm{CC}_{6} \mathrm{H}_{4}(\mathrm{OH})-o\right]_{2}$ were collected from the CCDC database ${ }^{10}$. The FTIR spectra of the compound, presented in Figure 1, have been recorded on a Perkin-Elmer Spectrum BX FTIR spectrophotometer in the frequency range 4000 to $400 \mathrm{~cm}^{-1}$.

\section{Computational methods}

\section{Classical mechanics calculations}

Normal coordinate calculations were performed using the program developed by Shimanouchi ${ }^{11}$ following the Wilson GF matrix method ${ }^{8}$. This method describes the motion in terms of the internal coordinates, which are changes in bond lengths, bond angles and those out of plane bending and dihedral angles. The force constants in terms of these coordinates can easily be visualized and have a physical meaning. The Urey Bradley force 
field is used in our calculations. It incorporates intra unit interactions and interactions due to the neighboring units, in addition to the bonded interactions. It also includes the interactions between non-bonded atoms. For the assignments the force constants were initially taken from the reported literature and later modified to give the "best fit" results with the observed FT-IR spectra (Figure 2) ${ }^{12-16}$. All force constants for the title compound are given in Table 1.

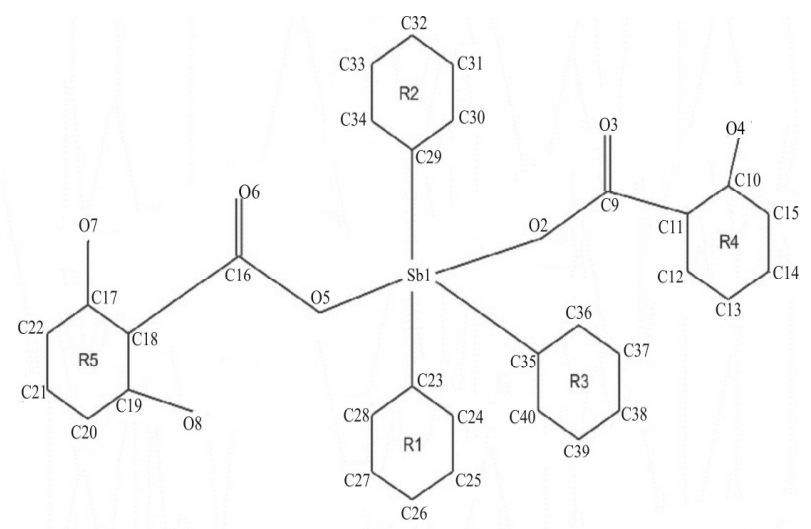

Figure 1. Model molecular structure of triphenylantimony(V)-o-salicylate $\mathrm{SbPh}_{3}\left(\mathrm{O}_{2} \mathrm{CC}_{6} \mathrm{H}_{4}(\mathrm{OH})-o\right]_{2}$

Table 1. Internal coordinates and force constant values (mdynes/Á) of the title compound

\begin{tabular}{ccc}
\hline S. No. & Internal Coordinates & Force constant values \\
\hline 1 & $v(\mathrm{C}-\mathrm{Sb})$ & 2.150 \\
2 & $v(\mathrm{O}-\mathrm{Sb})$ & 2.350 \\
3 & $v(\mathrm{C}-\mathrm{O}) \mathrm{adj}-\mathrm{Sb}$ & 4.200 \\
4 & $v(\mathrm{C}=\mathrm{O})$ adj-Sb & 7.370 \\
5 & $v(\mathrm{C}-\mathrm{O}) \mathrm{R} 1-\mathrm{O}$ & 4.120 \\
6 & $v(\mathrm{C}-\mathrm{O}) \mathrm{R} 2-\mathrm{O}$ & 5.300 \\
7 & $v(\mathrm{C}-\mathrm{C}) \mathrm{adj}-\mathrm{C}=\mathrm{O}$ & 4.360 \\
8 & $v(\mathrm{C}-\mathrm{C}) \mathrm{R} 4-\mathrm{adj}-\mathrm{O}$ & 4.020 \\
9 & $v(\mathrm{C}-\mathrm{C}) \mathrm{R} 5-\mathrm{adj}-\mathrm{O}$ & 4.000 \\
10 & $v(\mathrm{C}-\mathrm{C}) \mathrm{R} 2-\mathrm{adj}-\mathrm{Sb}$ & 5.665 \\
11 & $v(\mathrm{C}-\mathrm{C}) \mathrm{R} 2-\mathrm{adj}-\mathrm{Sb}$ & 5.630 \\
12 & $v(\mathrm{C}-\mathrm{C}) \mathrm{R} 3-\mathrm{adj}-\mathrm{Sb}$ & 5.635 \\
13 & $\phi(\mathrm{C}-\mathrm{Sb}-\mathrm{O})$ & 0.300 \\
14 & $\phi(\mathrm{O}-\mathrm{Sb}-\mathrm{O})$ & 0.250 \\
15 & $\phi(\mathrm{C}-\mathrm{Sb}-\mathrm{C})$ & 0.250 \\
16 & $\phi(\mathrm{Sb}-\mathrm{O}-\mathrm{C})$ & 0.105 \\
17 & $\phi(\mathrm{O}-\mathrm{C}=\mathrm{C}) \mathrm{adj}-\mathrm{Sb}$ & 1.125 \\
18 & $\phi(\mathrm{O}-\mathrm{C}-\mathrm{C}) \mathrm{adj}-\mathrm{Sb}$ & 0.310 \\
19 & $\phi(\mathrm{O}=\mathrm{C}-\mathrm{C}) \mathrm{adj}-\mathrm{Sb}$ & 1.350 \\
20 & $\phi(\mathrm{C}-\mathrm{C}-\mathrm{O}) \mathrm{adj}-\mathrm{R} 4$ & 0.790 \\
21 & $\phi(\mathrm{C}-\mathrm{C}-\mathrm{C})$ adj-R4 & 0.750 \\
\hline
\end{tabular}

Contd.... 


\begin{tabular}{ccc}
\hline 22 & $\phi(\mathrm{C}-\mathrm{C}-\mathrm{C}) \mathrm{R}-\mathrm{adj}-\mathrm{C}$ & 0.600 \\
23 & $\phi(\mathrm{C}-\mathrm{C}-\mathrm{C}) \mathrm{R} 4$ & 0.720 \\
24 & $\phi(\mathrm{C}-\mathrm{C}-\mathrm{O}) \mathrm{adj}-\mathrm{R} 4$ & 0.630 \\
25 & $\phi(\mathrm{C}-\mathrm{C}-\mathrm{O}) \mathrm{adj}-\mathrm{R} 5$ & 0.760 \\
26 & $\phi(\mathrm{C}-\mathrm{C}-\mathrm{C}) \mathrm{adj}-\mathrm{R} 5$ & 0.770 \\
27 & $\phi(\mathrm{C}-\mathrm{C}-\mathrm{C}) \mathrm{R} 5$ & 0.600 \\
28 & $\phi(\mathrm{C}-\mathrm{C}-\mathrm{C}) \mathrm{R} 1$ & 0.760 \\
29 & $\phi(\mathrm{Sb}-\mathrm{C}-\mathrm{C})$ & 0.300 \\
30 & $\phi(\mathrm{C}-\mathrm{C}-\mathrm{C}) \mathrm{R} 2$ & 0.660 \\
31 & $\phi(\mathrm{C}-\mathrm{C}-\mathrm{C}) \mathrm{R} 3$ & 0.745 \\
32 & $\omega(\mathrm{C}=\mathrm{O}) \mathrm{adj}-\mathrm{R} 4$ & 0.310 \\
33 & $\omega(\mathrm{C}-\mathrm{O}) \mathrm{R} 4$ & 0.257 \\
34 & $\omega(\mathrm{C}-\mathrm{O}) \mathrm{adj}-\mathrm{R} 5$ & 0.450 \\
35 & $\omega(\mathrm{C}-\mathrm{O}) \mathrm{adj}-\mathrm{R} 5$ & 0.250 \\
36 & $\omega(\mathrm{C}-\mathrm{O}) \mathrm{R} 5$ & 0.250 \\
37 & $\tau(\mathrm{Sb}-\mathrm{O})$ & 0.045 \\
38 & $\tau(\mathrm{Sb}-\mathrm{C}) \mathrm{R} 3$ & 0.045 \\
39 & $\tau(\mathrm{Sb}-\mathrm{C}) \mathrm{R} 1$ & 0.045 \\
40 & $\tau(\mathrm{Sb}-\mathrm{O}) \mathrm{R} 1$ & 0.045 \\
41 & $\tau(\mathrm{Sb}-\mathrm{C}) \mathrm{R} 2$ & 0.045 \\
42 & $\tau(\mathrm{O}-\mathrm{C}) \mathrm{R} 4$ & 0.055 \\
43 & $\tau(\mathrm{O}-\mathrm{C}) \mathrm{R} 5$ & 0.055 \\
44 & $\tau(\mathrm{C}-\mathrm{C}) \mathrm{R} 4-\mathrm{C}=\mathrm{O}$ & 0.055 \\
45 & $\tau(\mathrm{C}-\mathrm{C}) \mathrm{R} 4$ & 0.055 \\
46 & $\tau(\mathrm{C}-\mathrm{C}) \mathrm{R} 5$ & 0.055 \\
47 & $\tau(\mathrm{C}-\mathrm{C}) \mathrm{R} 1$ & 0.055 \\
48 & $\tau(\mathrm{C}-\mathrm{C}) \mathrm{R} 2$ & 0.058 \\
49 & $\tau(\mathrm{C}-\mathrm{C}) \mathrm{R} 3$ & 0.005 \\
\hline & &
\end{tabular}

Note:

1. Here v means the stretching vibration between the atoms.

2. Here $\phi$ means the angle inplane-bending between the three atoms.

3. Here wreans the out-of-plane bending or wagging between the atoms.

4. Here $\tau$ means the torsional vibration between the atoms.

5. R-stands for ring and adj-stands for adjacent.

6. The values in brackets denotes the non-bonded force constants values.

7. R1-O etc. stands for outside the ring RI etc.

The computer program developed by Shimanouchi ${ }^{11}$ was used for the calculation of vibrational frequencies and potential energy distribution (PED), which made it possible to obtain a detailed description of the nature of vibrational bands. Potential energy distribution provides quantification of the contribution of internal coordinate to a normal coordinate ${ }^{17,18}$. For that purpose, the contribution of the diagonal force constant of internal coordinate to the vibrational eigen value is expressed as a percentage. All semi-empirical calculations were performed by Mopac 2007 package ${ }^{6}$. Assignment of frequency modes was performed by graphical user interface Winmostar ${ }^{19}$. 
The title compound triphenylantimony(V)-o-Salicylate $\mathrm{SbPh}_{3}\left[\mathrm{O}_{2} \mathrm{CC}_{6} \mathrm{H}_{4}(\mathrm{OH})-o\right]_{2}$ has 65 atoms, however to reduce the problem to manageable dimensions $\mathrm{CH}, \mathrm{OH}$ etc. have been treated as mass points with a mass of 13, 16 etc. respectively. This does not in any way disturb the accuracy of the results presented here. This is because the frequencies belonging to these can well be designated as group frequencies and many of them being in the higher range do not mix with other modes. With this approximation the triphenylantimony(V)-osalicylate reduces to $40(\mathrm{~N})$ atoms problem with $114(3 \mathrm{~N}-6)$ normal modes of vibrations ${ }^{8}$.



Figure 2. FT-IR spactra of Triphenylanytimony(V)-o-salicylate.

\section{Quantum chemical calculations}

\section{Atomic charge distribution}

The knowledge of the charge distributions is essential for the interpretation of molecular properties. The atomic charges for all the atoms of the title compound calculated by PM3 method in gas phase are presented in Table 2. As seen from this table, the oxygen atoms like O1, O2, O4 and $\mathrm{O} 5$ have bigger negative atomic charges with values as $-0.56521,-0.55328,-0.60315$ and 0.53765 units respectively, suggesting that they may be potential sites to react with charged moieties/ions. Besides the oxygen atoms some carbon atoms like C3, C6, C7, C10, C12, C14, $\mathrm{C} 15, \mathrm{C} 21$ and $\mathrm{C} 27$ also have relatively higher negative charge values than the other carbon atoms in the molecule, and their respective values are $-0.24062,-0.0296,-0.18295,-0.34722,-0.23683$, $-0.2352,-0.16773,-0.16816$ and -0.21622 units. This data of the charge distribution of atoms suggests that the oxygen atoms are relatively stronger potential sites than the carbon atoms.

\section{Results and Discussion}

In the present work the observed frequencies agree with the calculated ones within $10 \mathrm{~cm}^{-1}$. In the assignment of the normal modes as given in Table 2 ( $a, b \& c)$, only the dominant 
potential energy distributions (PED) are considered. The corresponding force constants values are given in Table 1, which includes the force constants values for bonded as well as non-bonded interactions. The non-bonded parameters help to bring a molecule into its best spatial orientation. The physical effects represented by these parameters are Vander Waals and electrostatic forces. Identification with the experimental data has been made on the basis of potential energy distribution, line profile, line intensities and the presence/absence of a given mode in similar molecules ${ }^{20-23}$.

Table 2(a). Calculated and observed back-bone \& mixed modes

\begin{tabular}{|c|c|c|c|}
\hline \multicolumn{2}{|c|}{$\begin{array}{c}\text { Calculated Freq } \\
\mathrm{cm}^{-1}\end{array}$} & \multirow{2}{*}{$\begin{array}{l}\text { Observed Freq } \\
-\quad \text { FTIR, } \mathrm{cm}^{-1}\end{array}$} & \multirow[t]{2}{*}{ Assignment in \% Potential energy distribution (PED) } \\
\hline Wilson GF & PM3 & & \\
\hline 1450 & 1459 & $1445, \mathrm{~m}$ & $\begin{array}{l}v(\mathrm{C}-\mathrm{C}) \mathrm{R} 1-\mathrm{O}[49]+v(\mathrm{C}-\mathrm{C}) \mathrm{ad}-\mathrm{C}=\mathrm{O}[33]+\mathrm{v}(\mathrm{C}-\mathrm{C}) \mathrm{R} 3- \\
\text { asym[PM3] }\end{array}$ \\
\hline 1387 & 1368 & $1380, \mathrm{vs}$ & $\begin{array}{l}v(\mathrm{C}-\mathrm{C}) \mathrm{R} 5-\mathrm{O}[46]+v(\mathrm{C}-\mathrm{O}) \mathrm{R} 1-\mathrm{O}[18]+v(\mathrm{O}=\mathrm{C}) \mathrm{ad}-\mathrm{Sb}[13]+ \\
+v(\mathrm{C}-\mathrm{O}) \mathrm{adj}-\mathrm{Sb}[22]+\mathrm{v}(\mathrm{O}-\mathrm{C}) \mathrm{ad}-\mathrm{R} 5 \& \mathrm{Sb}[\mathrm{PM} 3]\end{array}$ \\
\hline 1352 & 1360 & 1353 , vs & $\begin{array}{l}v(\mathrm{C}-\mathrm{C}) \mathrm{R} 2-\mathrm{O}[53]+v(\mathrm{C}-\mathrm{C}) \mathrm{R} 2-\mathrm{O}[29]+v(\mathrm{O}-\mathrm{C}) \mathrm{ad}- \\
\mathrm{R} 4 \& \mathrm{Sb}[\mathrm{PM} 3]\end{array}$ \\
\hline 1253 & 1229 & $1253, \mathrm{~s}$ & $\begin{array}{l}v(\mathrm{C}-\mathrm{C}) \mathrm{R} 2-\mathrm{O}[43]+v(\mathrm{O}-\mathrm{C}) \mathrm{ad}-\mathrm{Sb}[22]+v(\mathrm{C}-\mathrm{C}) \mathrm{ad}-\mathrm{O}[19]+ \\
+v(\mathrm{O}-\mathrm{C}) \mathrm{adj}-\mathrm{R} 4 \& \mathrm{Sb}[\mathrm{PM} 3]+\phi(\mathrm{C}-\mathrm{C}-\mathrm{C}) \mathrm{R} 2[\mathrm{PM} 3]\end{array}$ \\
\hline 1161 & 1164 & $1153, \mathrm{~s}$ & $\begin{array}{l}v(\mathrm{C}-\mathrm{C}) \mathrm{R} 1-\mathrm{O}[55]+v(\mathrm{O}-\mathrm{C}) \mathrm{R} 1-\mathrm{O}[32]+\phi(\mathrm{C}-\mathrm{C}-\mathrm{C}) \mathrm{R} 4[11]+ \\
+\mathrm{R} 2-\text { puck}[\mathrm{PM} 3]+\phi(\mathrm{C}-\mathrm{C}-\mathrm{C}) \mathrm{R} 1[\mathrm{PM} 3]\end{array}$ \\
\hline 1061 & $\ldots \ldots$ & $1070, \mathrm{~m}$ & $v(\mathrm{C}-\mathrm{C}) \mathrm{R} 2-\mathrm{O}[53]+v(\mathrm{C}-\mathrm{O}) \mathrm{ad}-\mathrm{Sb}[18]+\phi(\mathrm{C}-\mathrm{C}-\mathrm{C}) \mathrm{R} 5[11]$ \\
\hline 1033 & $\ldots \ldots$ & 1034, wsh & $v(\mathrm{C}-\mathrm{O}) \mathrm{ad}-\mathrm{Sb}[30]+v(\mathrm{C}-\mathrm{C}) \mathrm{R} 1-\mathrm{O}[24]+\phi(\mathrm{C}-\mathrm{C}-\mathrm{C}) \mathrm{R} 4[21]$ \\
\hline 762 & 762 & $762, \mathrm{~s}$ & $\begin{array}{l}\phi(\mathrm{C}-\mathrm{C}-\mathrm{C}) \mathrm{R} 4[49]+v(\mathrm{Sb}-\mathrm{O})[15]+v(\mathrm{C}-\mathrm{O}) \mathrm{R} 1-\mathrm{O}[10]+ \\
+v(\mathrm{C}-\mathrm{C}) \mathrm{R} 2-\text {-asym[PM3] + v(C-O)ad-Sb-R4[PM3] }\end{array}$ \\
\hline 748 & 736 & 745 , vs & $\begin{array}{l}\phi(\mathrm{Sb}-\mathrm{O}-\mathrm{C})[27]+v(\mathrm{Sb}-\mathrm{O})[16]+v(\mathrm{C}=\mathrm{O}) \text { adj-Sb[16]+ } \phi(\mathrm{O}-\mathrm{C}- \\
\mathrm{C}) \mathrm{ad}-\mathrm{Sb}[14]+\nu(\mathrm{C}-\mathrm{O}) \mathrm{ad}-\mathrm{Sb}[10]+\mathrm{R} 4-\operatorname{rock}[\mathrm{PM} 3]+ \\
+\phi(\mathrm{C}-\mathrm{C}-\mathrm{O}) \text { adj-R4[PM3 }]\end{array}$ \\
\hline 707 & 703 & $704, \mathrm{~m}$ & $\begin{array}{l}\phi(\mathrm{C}-\mathrm{C}-\mathrm{C}) \mathrm{R} 5[43]+v(\mathrm{Sb}-\mathrm{O})[26]+v(\mathrm{C}-\mathrm{C}) \mathrm{ad}-\mathrm{O}[10]+ \\
+\phi(\mathrm{C}-\mathrm{C}-\mathrm{O}) \text { adj-R4[PM3] + }(\text { Sb-O-C }) \text { adj-R5[PM3] }\end{array}$ \\
\hline 650 & 642 & 641, wsh & $\begin{array}{l}v(\mathrm{Sb}-\mathrm{O})[31]+v(\mathrm{C}-\mathrm{C}) \mathrm{R} 1-\mathrm{O}[24]+\phi(\mathrm{C}-\mathrm{C}-\mathrm{C}) \mathrm{R} 4[10]+ \\
+(\mathrm{O}=\mathrm{C}-\mathrm{O}) \text { adj-R4-sciss[PM3] }+\phi(\mathrm{Sb}-\mathrm{O}-\mathrm{C}) \text { adj-R4[PM3 }]\end{array}$ \\
\hline 455 & 469 & $460, \mathrm{~s}$ & $\begin{array}{l}\phi(\mathrm{C}-\mathrm{C}-\mathrm{C}) \mathrm{R} 5[35]+\phi(\mathrm{C}-\mathrm{C}-\mathrm{O}) \mathrm{R} 5[20]+\phi(\mathrm{C}-\mathrm{C}-\mathrm{C}) \mathrm{R} 5[14]+ \\
v(\mathrm{C}-\mathrm{O}) \mathrm{R} 1-\mathrm{O}[10]+\mathrm{R} 4-\text { tors}[\mathrm{PM} 3]+\omega(\mathrm{C}=\mathrm{O}) \text { ad-R5[PM3] }\end{array}$ \\
\hline 446 & 445 & 447, wsh & $\begin{array}{l}\phi(\mathrm{C}-\mathrm{C}-\mathrm{O}) \mathrm{ad}-\mathrm{R} 1-\mathrm{O}[32]+v(\mathrm{Sb}-\mathrm{O})[14]+v(\mathrm{C}-\mathrm{C}) \mathrm{R} 1 \mathrm{ad}- \\
\mathrm{O}[12]+\mathrm{R} 2-\operatorname{rock}[\mathrm{PM} 3]+\phi(\mathrm{Sb}-\mathrm{C}-\mathrm{C}) \text { adj-R2[PM3] }\end{array}$ \\
\hline
\end{tabular}

\section{Back-bone \& mixed modes}

The modes which includes the vibrations of $v(\mathrm{Sb}-\mathrm{O}), \mathrm{v}(\mathrm{C}-\mathrm{O}), \mathrm{v}(\mathrm{C}-\mathrm{C})$ out-r stretches, $\phi(\mathrm{C}-$ $\mathrm{C}-\mathrm{O}), \phi(\mathrm{C}-\mathrm{C}=\mathrm{O}), \phi(\mathrm{Sb}-\mathrm{O}-\mathrm{C}), \phi(\mathrm{O}-\mathrm{Sb}-\mathrm{O})$ in plane bendings, $\tau(\mathrm{Sb}-\mathrm{O}-\mathrm{C}-\mathrm{C}), \tau(\mathrm{C}-\mathrm{Sb}-\mathrm{O}-\mathrm{C})$ torsions and their mixtures are termed as back bone modes. Steric interactions between atoms that bond distances away are accounted for with this term. All back-bone and mixed modes are given in Table 2(a).

In the FTIR spectra a medium intensity peak is observed at $1445 \mathrm{~cm}^{-1}$, which is calculated at $1450 \mathrm{~cm}^{-1}$ from Wilson GF method with the stretching modes $v(C-C) R 1$ $\mathrm{O}[49 \%]$ and $\mathrm{v}(\mathrm{C}-\mathrm{C})$ adj-C $=\mathrm{O}[33 \%]$ PED's (potential energy distributions), whereas it is 
found to be at $1459 \mathrm{~cm}^{-1}$ due to semi-empirical PM3 method with asymmetric stretching of $v(C-C) R 3$. This peak is reported ${ }^{24}$ in the range, $1616-1455 \mathrm{~cm}^{-1}$. A very intense band is obtained in the FTIR spectra with two absorption peaks one at $1380 \mathrm{~cm}^{-1}$ and other at $1353 \mathrm{~cm}^{-1}$, and these are calculated at $1387 \mathrm{~cm}^{-1}$ and 1352 from Wilson GF method, with vibrational modes $v(\mathrm{C}-\mathrm{C}) \mathrm{R} 1-\mathrm{O}[46 \%], \mathrm{v}(\mathrm{C}-\mathrm{O}) \mathrm{R} 1-\mathrm{O}[18 \%]$ mixed with other modes in small contributions for first peak and $v(\mathrm{C}-\mathrm{C}) \mathrm{R} 2-\mathrm{O}[53 \%]$ and $\mathrm{v}(\mathrm{C}-\mathrm{C}) \mathrm{R} 2[29 \%]$ for the second. This band is calculated at 1368 and $1360 \mathrm{~cm}^{-1}$, with modes of vibrations as $v(\mathrm{C}-\mathrm{O})$ adj-R5\&Sb and $v(\mathrm{C}-\mathrm{C})$ adj-R4\&Sb, with PM3 method, respectively. This mode is reported in the range $1350-1315 \mathrm{~cm}^{-1}$ in the literature ${ }^{24}$. A strong peak is observed at $1253 \mathrm{~cm}^{-1}$ in the spectra and is calculated at $1253 \mathrm{~cm}^{-1}$ from GF matrix method, having modes of vibrations as $\mathrm{v}(\mathrm{C}$ O)out-R[22\%] and $v(\mathrm{C}-\mathrm{C}) \mathrm{R} 2\left[43 \%\right.$ ], whereas from PM3 method it is obtained at $1229 \mathrm{~cm}^{-1}$ with vibrational modes as $v(\mathrm{C}-\mathrm{O})$ adj-R4\&Sb $\{\mathrm{PM} 3\}$ and $\phi(\mathrm{C}-\mathrm{C}-\mathrm{C}) \mathrm{R} 2\{\mathrm{PM} 3\}$. The phenolic (C-O) stretching mode is reported ${ }^{27}$ at $1280 \mathrm{~cm}^{-1}$, which suggests the participation of oxygen in $(\mathrm{C}-\mathrm{O}-\mathrm{Sb})$ bonding ${ }^{26,27}$. A strong peak is obtained in the FTIR spectra at $1153 \mathrm{~cm}^{-1}$ and is calculated from GF matrix method at $1161 \mathrm{~cm}^{-1}$ with vibrational modes $v(\mathrm{C}-\mathrm{O}) \mathrm{R} 1-\mathrm{O}[32 \%]$, $v(\mathrm{C}-\mathrm{C}) \mathrm{R} 1-\mathrm{O}[55 \%]$ and $\phi(\mathrm{C}-\mathrm{C}-\mathrm{C}) \mathrm{R} 4[11 \%]$, this peak is calculated from PM3 method at 1164 $\mathrm{cm}^{-1}$ attributing to the modes of vibrations as ring $\mathrm{R} 2$ breathing(or puckering) and in plane bending $\phi(C-C-C) R 1$. A medium intense peak is observed at $1070 \mathrm{~cm}^{-1}$ and is calculated at $1061 \mathrm{~cm}^{-1}$ from GF matrix method with vibrational modes $v(\mathrm{C}-\mathrm{O})$ out-R[18\%], v(C-C)R2$\mathrm{O}[53 \%]$ and $\phi(\mathrm{C}-\mathrm{C}-\mathrm{C}) \mathrm{R} 2[11 \%]$, whereas this mode is absent in the PM3 method. A weak peak is observed at $1034 \mathrm{~cm}^{-1}$ and is calculated at $1033 \mathrm{~cm}^{-1}$ with modes of vibrations as $v(\mathrm{C}-\mathrm{O})$ out-r[30\%], $v(\mathrm{C}-\mathrm{C}) \mathrm{R} 1[24 \%]$ and $\phi(\mathrm{C}-\mathrm{C}-\mathrm{C}) \mathrm{R} 3[21 \%]$.

A strong peak is observed in FTIR spectra at $762 \mathrm{~cm}^{-1}$ and it is calculated at $762 \mathrm{~cm}^{-1}$ from GF matrix method, with modes of vibrations $v(\mathrm{Sb}-\mathrm{O})[15 \%], \phi(\mathrm{C}-\mathrm{C}-\mathrm{C}) \mathrm{R} 4[49 \%]$ and $v(\mathrm{C}-\mathrm{O}) \mathrm{R} 1-\mathrm{O}[14 \%]$, and it is also calculated at $762 \mathrm{~cm}^{-1}$, from the PM3 method, attributing to the stretching modes as $v(\mathrm{C}-\mathrm{C}) \mathrm{R} 2$-asym and $\mathrm{v}(\mathrm{C}-\mathrm{O})$. A very strong absorption peak is observed at $745 \mathrm{~cm}^{-1}$ and is calculated by GF matrix method at $748 \mathrm{~cm}^{-1}$ having vibrational modes as $v(\mathrm{Sb}-\mathrm{O})[16 \%], \phi(\mathrm{Sb}-\mathrm{O}-\mathrm{C})[27 \%], v(\mathrm{C}=\mathrm{O})[16 \%], \phi(\mathrm{C}-\mathrm{C}-\mathrm{O})[14 \%]$ and $v(\mathrm{C}-\mathrm{O})$ out$\mathrm{R}[10 \%]$, however, it is found to be at $736 \mathrm{~cm}^{-1}$ with vibrational modes as ring-4(R4) rocking and in-plane bending of $\phi(\mathrm{C}-\mathrm{O}-\mathrm{C})$ adj-R $4\{\mathrm{PM} 3\}$. These two peaks obtained at $762 \mathrm{~cm}^{-1}$ and $745 \mathrm{~cm}^{-1}$ are symmetric modes, which seems to be involve in secondary bonding interactions, as suggested by low PED values (15\% and $16 \%$ resp.) of $v(\mathrm{Sb}-\mathrm{O})$ mode and these are in good agreement as reported by Shanker et $a l^{28}$. A medium intense peak is observed at $704 \mathrm{~cm}^{-1}$ and it is calculated at $707 \mathrm{~cm}^{-1}$ by classical GF matrix method, having vibrational modes $v(\mathrm{Sb}-\mathrm{O})[26 \%]$ and $\phi(\mathrm{C}-\mathrm{C}-\mathrm{C}) \mathrm{R} 5[43 \%]$, and it is calculated at $703 \mathrm{~cm}^{-1}$, having modes of vibrations as $\phi(\mathrm{C}-\mathrm{O}-\mathrm{C})$ adj-R $4\{\mathrm{PM} 3\}$ and $\phi(\mathrm{Sb}-\mathrm{O}-\mathrm{C})\{\mathrm{PM} 3\}$. A weak shoulder absorption peak is observed at $641 \mathrm{~cm}^{-1}$ which is calculated at $650 \mathrm{~cm}^{-1}$ from Wilson GF matrix method, with modes of vibration as $v(\mathrm{Sb}-\mathrm{O})[30 \%]$ and $\mathrm{v}(\mathrm{C}-\mathrm{C}) \mathrm{R} 1[23 \%]$, and it is found at $642 \mathrm{~cm}^{-1}$ attributing to the scissoring of $(\mathrm{O}=\mathrm{C}-\mathrm{O})$ adjR4 and in-plane bending of $\phi(\mathrm{Sb}$ $\mathrm{O}-\mathrm{C})$ adj-R4\{PM3 . This band is a bit lower as reported by Shanker et al. ${ }^{28}$, and higher as compared to the reported bands by Khosa $e t a l^{29}$. This band range for $\mathrm{v}(\mathrm{Sb}-\mathrm{O})$ which is mass sensitive mode due to the heavy antimony atom, seems to be one of the characteristic mode, of the title compound, which is probably due to secondary interaction between antimony and oxygen atoms. A band in lower frequency range with one strong and one weak shoulder absorption peaks are observed in FTIR spectra. The strong peak is observed at $460 \mathrm{~cm}^{-1}$ and is calculated from classical method, at $455 \mathrm{~cm}^{-1}$ with modes of vibrations $\phi(C-C-O)[20 \%]$, 
$\phi(\mathrm{C}-\mathrm{C}-\mathrm{C}) \mathrm{R} 5[48 \%]$ and $v(\mathrm{C}-\mathrm{O})$ out- $\mathrm{R}[10 \%]$ and it is calculated from quantum mechanical method at $469 \mathrm{~cm}^{-1}$ with torsional motion of ring $\mathrm{R} 4$ and out of plane wagging $\omega(\mathrm{C}=\mathrm{O})$ adj-R5, whereas the weak shoulder peak is observed at $447 \mathrm{~cm}^{-1}$ and is calculated at $446 \mathrm{~cm}^{-1}$ and 445 from GF matrix and PM3 methods, with modes of vibrations $\phi(\mathrm{C}-\mathrm{C}-\mathrm{O})[32 \%], v(\mathrm{Sb}-\mathrm{O})[14 \%]$, $\phi(\mathrm{C}-\mathrm{C}-\mathrm{C}) \mathrm{R} 1[10 \%]$ and rocking of ring $\mathrm{R} 2$, in-plane bending $\phi(\mathrm{Sb}-\mathrm{C}-\mathrm{C})$ adj-R2 respectively. The in-plane bending mode $\phi(C-C-C) R$ is reported ${ }^{30}$ at $522 \mathrm{~cm}^{-1}$ and $495 \mathrm{~cm}^{-1}$.

\section{Side-chain modes}

The vibrational modes like $v(\mathrm{Sb}-\mathrm{C})$ and $v(\mathrm{C}=\mathrm{O})$ stretching, $\phi(\mathrm{Sb}-\mathrm{C}-\mathrm{C}), \phi(\mathrm{C}-\mathrm{Sb}-\mathrm{C})$, $\phi(\mathrm{C}-\mathrm{Sb}-\mathrm{O})$ in-plane bending, $\omega(\mathrm{C}=\mathrm{O})$ wagging and $\tau(\mathrm{Sb}-\mathrm{C}-\mathrm{C}-\mathrm{C})$ and $\tau(\mathrm{O}=\mathrm{C}-\mathrm{C}-\mathrm{C})$ torsions are termed as "Side chain Modes". All side chain modes are presented in Table 2 (b).

Table 2 (b). Calculated and observed side chain modes

\begin{tabular}{|c|c|c|c|}
\hline \multicolumn{2}{|c|}{ Calculated freq, $\mathrm{cm}^{-1}$} & \multirow{2}{*}{$\begin{array}{l}\text { Observed freq } \\
\text { FTIR, } \mathrm{cm}^{-1}\end{array}$} & \multirow{2}{*}{ Assignment in $\%$ potential energy distribution, PED } \\
\hline Wilson GF & PM3 & & \\
\hline 1632 & 1645 & $1638(\mathrm{~m})$ & $\begin{array}{l}v(\mathrm{O}=\mathrm{C}) \text { ad-Sb }[51]+v(\mathrm{C}-\mathrm{C}) \text { ad-C }=\mathrm{O}[16]+ \\
\phi(\mathrm{C}-\mathrm{C}-\mathrm{O}) \text { adj- } \mathrm{Sb}[14]+v(\mathrm{O}=\mathrm{C}) \text { ad-Sb\&R4[PM3] }\end{array}$ \\
\hline 1617 & ..... & 1625 & $\begin{array}{l}v(\mathrm{O}=\mathrm{C}) \text { ad-Sb }[54]+\phi(\mathrm{C}-\mathrm{C}-\mathrm{O}) \mathrm{ad}-\mathrm{Sb}[14]+v(\mathrm{C}- \\
\mathrm{C}) \mathrm{ad}-\mathrm{C}=\mathrm{O}[22]\end{array}$ \\
\hline 538 & 535 & $535(w)$ & $\begin{array}{l}\omega(\mathrm{C}=\mathrm{O}) \mathrm{ad}-\mathrm{R} 4[65]+\tau(\mathrm{C}-\mathrm{O}) \mathrm{R} 4[15]+\mathrm{R} 4- \\
\text { twis[PM3]+ +(C-O)-R4-sciss[PM3] }\end{array}$ \\
\hline 378 & $\ldots \ldots$ & ---- & $\begin{array}{l}v(\mathrm{Sb}-\mathrm{C})[55]+\phi(\mathrm{C}-\mathrm{C}-\mathrm{C}) \mathrm{R} 3[22]+v(\mathrm{C}-\mathrm{C}) \\
\mathrm{R} 3-\mathrm{Sb}[12]+\phi(\mathrm{C}-\mathrm{C}-\mathrm{Sb})[11]\end{array}$ \\
\hline 302 & $\cdots \cdots$ & $\cdots \cdots$ & $\begin{array}{l}v(\mathrm{Sb}-\mathrm{C})[55]+\phi(\mathrm{C}-\mathrm{Sb}-\mathrm{O})[29]+\phi(\mathrm{C}-\mathrm{C}-\mathrm{C})[12]+ \\
\phi(\mathrm{C}-\mathrm{C}-\mathrm{Sb})[11]\end{array}$ \\
\hline 240 & 280 & $\ldots$. & $\begin{array}{l}v(\mathrm{Sb}-\mathrm{C})[28]+\phi(\mathrm{C}-\mathrm{C}-\mathrm{Sb})[16]+\phi(\mathrm{C}-\mathrm{C}-\mathrm{C})[13]+ \\
v(\mathrm{Sb}-\mathrm{C})[\mathrm{PM} 3]+\phi(\mathrm{C}-\mathrm{C}-\mathrm{Sb})[\mathrm{PM} 3]\end{array}$ \\
\hline
\end{tabular}

The presence of $v(\mathrm{C}=\mathrm{O})$ double bond, makes the structure of the title compound fairly rigid and the formation of hydrogen bonds don't much disturb the charge distribution in the ring and side chains. The length of hydrogen bonds is also in support of this rigidity. In the FTIR spectra, an absorption band is obtained, with one medium intensity peak which is observed at $1638 \mathrm{~cm}^{-1}$ and it is calculated from classical mechanics Wilson GF matrix method at $1632 \mathrm{~cm}^{-1}$ comprising the vibrational modes as $v(\mathrm{C}=\mathrm{O})[51 \%] \mathrm{PED}, \phi(\mathrm{C}-\mathrm{C}-\mathrm{O})$ adj$\mathrm{Sb}[14 \%]$ and $v(\mathrm{C}-\mathrm{C}) \operatorname{adj}-\mathrm{C}=\mathrm{O}[16 \%]$, whereas, from quantum mechanical semi-empirical PM3 method, it is calculated at $1645 \mathrm{~cm}^{-1}$, with stretching $v(\mathrm{C}=\mathrm{O})$ adj-Sb-R4 stretching mode. A weak shoulder absorption peak which is observed $v(\mathrm{O}=\mathrm{C})$ ad-Sb [54\%], $\phi(\mathrm{C}-\mathrm{C}-\mathrm{O})$ ad$\mathrm{Sb}[14 \%]$ and $\mathrm{v}(\mathrm{C}-\mathrm{C})$ adj-C$=\mathrm{O}[22 \%]$. This stretching mode $\mathrm{v}(\mathrm{C}=\mathrm{O})$, is reported in the range $1750-1630 \mathrm{~cm}^{-1}$ in the literature ${ }^{27}$, so it is in good agreement with those calculated in this work. A weak absorption peak is observed in low frequency range at $535 \mathrm{~cm}^{-1}$ and is calculated at $538 \mathrm{~cm}^{-1}$ and $535 \mathrm{~cm}^{-1}$ from GF matrix and PM3 methods respectively, having vibrational modes $\omega(\mathrm{C}=\mathrm{O})$ adj-R4[65\%], $\tau(\mathrm{O}=\mathrm{C}-\mathrm{C}-\mathrm{C}) \mathrm{R} 4[15 \%]$ in $\mathrm{GF}$ matrix method and ring R4 twisting, (C-O)adj-R4 scissoring in PM3 method. The $v(\mathrm{Sb}-\mathrm{C})$ which is mass sensitive mode, is calculated in the lower frequency region which contains absorption peaks at $378 \mathrm{~cm}^{-1}$ with 56\% PED from Wilson method, one absorption peak is calculated at 302 $\mathrm{cm}^{-1}$ with $v(\mathrm{Sb}-\mathrm{C})[31 \%$ ] mixed with $\phi(\mathrm{C}-\mathrm{Sb}-\mathrm{O})[29 \%$ ]. An absorption peak is also calculated at $240 \mathrm{~cm}^{-1}$ from Wilson GF method and $280 \mathrm{~cm}^{-1}$ from PM3 method, with modes of 
vibrations $v(\mathrm{Sb}-\mathrm{C})[28 \%], \phi(\mathrm{C}-\mathrm{C}-\mathrm{Sb})[16 \%], \phi(\mathrm{C}-\mathrm{C}-\mathrm{C})[13 \%]$ and $v(\mathrm{Sb}-\mathrm{C})\{\mathrm{PM} 3\}, \phi(\mathrm{C}-\mathrm{C}-$ $\mathrm{Sb})\{\mathrm{PM} 3\}$ respectively. These peaks are reported in the frequency range $449-472 \mathrm{~cm}^{-1}$ by Shanker $e t a l^{28}$, in the frequency range $459-489 \mathrm{~cm}^{-1}$ by Khosa et $a l^{27}$ and at $234 \mathrm{~cm}^{-1}$ by Ludwig et $a l^{30}$ respectively.

\section{Ring modes}

In the title compound triphenylantimony $(\mathrm{V})-o$-Salicylate there are five benzene rings in which 3-rings R1, R2 and R3 are directly attached to the central antimony Sb atom and two rings $\mathrm{R} 4 \& \mathrm{R} 5$ are attached on left side and right side of central $\mathrm{Sb}$ atom respectively. The vibrations like $v(\mathrm{C}-\mathrm{C}) \mathrm{R}$ stretching, $\phi(\mathrm{C}-\mathrm{C}-\mathrm{C}) \mathrm{R}$ in-plane bending, $\omega(\mathrm{C}-\mathrm{O})$ wagging and $\tau(\mathrm{C}-\mathrm{C}-\mathrm{C}-\mathrm{C}) \mathrm{R}$ torsions, corresponding to these five ring atoms are termed as "ring modes". All the ring modes are given in the Table 2 (c).

Table 2 (c). Calculated and observed ring modes

\begin{tabular}{|c|c|c|c|}
\hline \multicolumn{2}{|c|}{$\begin{array}{l}\text { Calculated freq, } \\
\frac{\mathrm{cm}^{-1}}{\text { Wilson GF PM3 }} \\
\end{array}$} & $\begin{array}{l}\text { Observed freq } \\
\text { FTIR, } \mathrm{cm}^{-1}\end{array}$ & $\begin{array}{c}\text { Assignment in } \% \text { potential energy distribution, } \\
\text { PED }\end{array}$ \\
\hline$\ldots \ldots$ & 4838 & $3905, w$ & $v(\mathrm{O}-\mathrm{H})$ adj-R5[PM3] \\
\hline$\ldots \ldots$ & 4805 & $3856, \mathrm{~m}$ & $v(\mathrm{O}-\mathrm{H})$ adj-R4[PM3] \\
\hline$\ldots \ldots$ & 4041 & $3753, w$ & $v(\mathrm{C}-\mathrm{H}) \mathrm{R} 1[\mathrm{PM} 3]$ \\
\hline$\ldots \ldots$ & 4021 & $3678, \mathrm{~m}$ & $v(\mathrm{C}-\mathrm{H}) \mathrm{R} 2[\mathrm{PM} 3]$ \\
\hline$\ldots \ldots$ & 4020 & $3652, \mathrm{~m}$ & $v(\mathrm{C}-\mathrm{H}) \mathrm{R} 1[\mathrm{PM} 3]$ \\
\hline 1586 & 1599 & $1585, \mathrm{~m}$ & $\begin{array}{l}v(\mathrm{C}-\mathrm{C}) \mathrm{R} 3[95]+v(\mathrm{C}-\mathrm{C}) \mathrm{R} 2-\mathrm{sym}[\mathrm{PM} 3]+ \\
\phi(\mathrm{C}-\mathrm{C}-\mathrm{C}) \mathrm{R} 2[\mathrm{PM} 3]\end{array}$ \\
\hline 1564 & 1554 & $1563, \mathrm{w}$ & $\begin{array}{l}v(\mathrm{C}-\mathrm{C}) \mathrm{R} 1-\mathrm{Sb}[98]+v(\mathrm{C}-\mathrm{C}) \mathrm{R} 4- \\
\operatorname{sym}[\mathrm{PM} 3]+v(\mathrm{C}=\mathrm{O}) \text { adj-R4[PM3] }\end{array}$ \\
\hline 1510 & 1523 & $1508, w$ & $\begin{array}{l}v(\mathrm{C}-\mathrm{C}) \mathrm{R} 1-\mathrm{Sb}[98]+v(\mathrm{C}-\mathrm{C}) \mathrm{R} 4-\mathrm{asym}[\mathrm{PM} 3]+ \\
\phi(\mathrm{O}=\mathrm{C}-\mathrm{O}) \text { adj--R4[PM3] }\end{array}$ \\
\hline 1485 & 1486 & 1482, vs & $\begin{array}{l}v(\mathrm{C}-\mathrm{C}) \mathrm{R} 2-\mathrm{Sb}[71]+v(\mathrm{C}-\mathrm{C}) \mathrm{R} 1-\mathrm{Sb}[24]+v(\mathrm{C}- \\
\mathrm{C}) \mathrm{R} 5-\mathrm{sym}[\mathrm{PM} 3]++v(\mathrm{C}-\mathrm{C}) \text { adj-R5[PM3] }\end{array}$ \\
\hline 1434 & 1431 & $1437, \mathrm{~s}$ & $\begin{array}{l}v(\mathrm{C}-\mathrm{C}) \mathrm{R} 2-\mathrm{O}[42]+\mathrm{v}(\mathrm{C}-\mathrm{O}) \mathrm{R} 2-\mathrm{O}[24]+ \\
\mathrm{v}(\mathrm{O}=\mathrm{C}) \mathrm{ad}-\mathrm{Sb}[14]++\mathrm{v}(\mathrm{C}-\mathrm{C}) \mathrm{R} 5-\mathrm{sym}[\mathrm{PM} 3]+ \\
\mathrm{v}(\mathrm{C}-\mathrm{C}) \mathrm{adj}-\mathrm{R} 5[\mathrm{PM} 3]\end{array}$ \\
\hline 1331 & 1319 & $1326, \mathrm{msh}$ & $\begin{array}{l}v(\mathrm{C}-\mathrm{C}) \mathrm{R} 2-\mathrm{O}[98]+v(\mathrm{C}-\mathrm{C}) \mathrm{R} 2 \text {-asym[PM3] + } \\
\phi(\mathrm{C}-\mathrm{C}-\mathrm{C}) \mathrm{R} 2[\mathrm{PM} 3]\end{array}$ \\
\hline 1310 & 1291 & $1310, \mathrm{~s}$ & $\begin{array}{l}v(\mathrm{C}-\mathrm{C}) \mathrm{R} 1-\mathrm{O}[96]+v(\mathrm{C}-\mathrm{C}) \mathrm{R} 5 \text {-asym[PM3 }]+ \\
\phi(\mathrm{C}-\mathrm{C}-\mathrm{C}) \mathrm{R} 5[\mathrm{PM} 3]\end{array}$ \\
\hline 1265 & 1278 & 1270, wsh & $\begin{array}{l}v(\mathrm{C}-\mathrm{C}) \mathrm{R} 1-\mathrm{O}[59]+v(\mathrm{C}-\mathrm{C}) \mathrm{ad}-\mathrm{O}[16]+v(\mathrm{O}-\mathrm{C}) \mathrm{ad}-\mathrm{Sb}[14] \\
+v(\mathrm{C}-\mathrm{C}) \mathrm{R} 1 \text {-asym[PM3 }+\phi(\mathrm{C}-\mathrm{C}-\mathrm{C}) \mathrm{R} 1[\mathrm{PM} 3]\end{array}$ \\
\hline 1227 & 1223 & $1224, \mathrm{~m}$ & $\begin{array}{l}v(\mathrm{C}-\mathrm{C}) \mathrm{R} 1-\mathrm{Sb}[90]+\mathrm{R} 1-\text { puck}[\mathrm{PM} 3]+\mathrm{v}(\mathrm{C}-\mathrm{C}) \mathrm{R} 1 \\
\text { asym[PM3] }\end{array}$ \\
\hline 1193 & $\ldots$ & $1185, \mathrm{~m}$ & $v(\mathrm{C}-\mathrm{C}) \mathrm{R} 3-\mathrm{Sb}[86]$ \\
\hline 1181 & $\ldots$ & $1175, w$ & $v(\mathrm{C}-\mathrm{C}) \mathrm{R} 2-\mathrm{Sb}[86]$ \\
\hline 1092 & $\ldots$ & 1197, w & $v(\mathrm{C}-\mathrm{C}) \mathrm{R} 1-\mathrm{O}[70]+\phi(\mathrm{C}-\mathrm{C}-\mathrm{C}) \mathrm{R} 4[10]$ \\
\hline 1024 & $\ldots$ & $1021, \mathrm{w}$ & $\mathrm{v}(\mathrm{C}-\mathrm{C}) \mathrm{R} 1-\mathrm{Sb}[78]$ \\
\hline
\end{tabular}




\begin{tabular}{|c|c|c|c|}
\hline 997 & 955 & $998, \mathrm{~m}$ & $\begin{array}{l}v(\mathrm{C}-\mathrm{C}) \mathrm{R} 2-\mathrm{Sb}[73]+\phi(\mathrm{C}-\mathrm{C}-\mathrm{C}) \mathrm{R} 3[10]+\mathrm{R} 1 \& \mathrm{R} 3- \\
\text { deform[PM3] }\end{array}$ \\
\hline 919 & 908 & $916, \mathrm{w}$ & $\begin{array}{l}v(\mathrm{C}-\mathrm{C}) \mathrm{R} 1-\mathrm{O}[67]+\mathrm{v}(\mathrm{C}-\mathrm{O}) \mathrm{R} 1-\mathrm{O}[10]+\mathrm{R} 4- \\
\text { puck[PM3]++ v(C-O) adj-R4 [PM3] }\end{array}$ \\
\hline 866 & 871 & $864, \mathrm{~m}$ & $\begin{array}{l}\phi(\mathrm{C}-\mathrm{C}-\mathrm{C}) \mathrm{R} 3[85]+\phi(\mathrm{C}-\mathrm{C}-\mathrm{Sb})[10]+v(\mathrm{C}-\mathrm{O}) \\
\text { adj-R5 [PM3] }\end{array}$ \\
\hline 695 & 689 & $690, \mathrm{~s}$ & $\begin{array}{l}\tau(\mathrm{C}-\mathrm{C}) \mathrm{R} 1[62]+\tau(\mathrm{C}-\mathrm{C}) \mathrm{R} 3[18]+\tau(\mathrm{C}-\mathrm{C}) \mathrm{R} 5[17] \\
+\mathrm{R} 2 \text {-puck }\end{array}$ \\
\hline 665 & 669 & $667, \mathrm{~m}$ & $\begin{array}{l}\omega(\mathrm{C}-\mathrm{O}) \mathrm{R} 4[64]+\tau(\mathrm{C}-\mathrm{C}) \mathrm{R} 4[15]+\phi(\mathrm{C}-\mathrm{C}- \\
\mathrm{C}) \mathrm{R} 2 \& \mathrm{R} 3[\mathrm{PM} 3]\end{array}$ \\
\hline 621 & 619 & $615, w$ & $\begin{array}{l}\phi(\mathrm{C}-\mathrm{C}-\mathrm{C}) \mathrm{R} 2[56]+v(\mathrm{Sb}-\mathrm{C})[18]+v(\mathrm{C}-\mathrm{C}) \mathrm{R} 2- \\
\mathrm{Sb}[10]+\mathrm{R} 4-\mathrm{twis}\end{array}$ \\
\hline 571 & 580 & $581, \mathrm{w}$ & $\begin{array}{l}\phi(\mathrm{C}-\mathrm{C}-\mathrm{C}) \mathrm{R} 3[74]+\phi(\mathrm{C}-\mathrm{C}-\mathrm{Sb})[10]+\mathrm{R} 1-\text { twis }+ \\
\tau(\mathrm{C}-\mathrm{C}) \mathrm{R} 2[\mathrm{PM} 3]\end{array}$ \\
\hline 559 & 554 & $554, \mathrm{w}$ & $\begin{array}{l}\phi(\mathrm{C}-\mathrm{C}-\mathrm{C}) \mathrm{R} 1[84]+(\mathrm{O}=\mathrm{C}-\mathrm{O}) \mathrm{R} 5 \text {-rock}[\mathrm{PM} 3]+v(\mathrm{Sb}- \\
\mathrm{O})[\mathrm{PM} 3]++\omega(\mathrm{C}=\mathrm{O}) \text { adj=R5[PM3] }\end{array}$ \\
\hline 393 & 397 & $400, \mathrm{~m}$ & $\begin{array}{l}\tau(\mathrm{C}-\mathrm{C}) \mathrm{R} 2[91]+\mathrm{R} 5 \text {-rock }[\mathrm{PM} 3]+\phi(\mathrm{C}- \\
\mathrm{C}=\mathrm{O})[\mathrm{PM} 3]\end{array}$ \\
\hline
\end{tabular}

Note:

1. Here the abbreviation ad means adjacent outside.

2. $\quad R$-stands for the ring one, two etc.

3. Only the dominant modes are taken in most of the cases.

4. R-Sb etc. means attatched both ring and Sb etc.

The vibrations above $500 \mathrm{~cm}^{-1}$, were assigned for mono-substituted benzene derivates. In literature ${ }^{31,32}$ the observed frequencies of $1327 \mathrm{~cm}^{-1}$ was assigned as in-plane $v(C-C)$ stretching. The out of plane vibrations according to Whiffen ${ }^{33}$ are well known, although it is more difficult to find a good force field for these vibrations.

In this region, moderately intense bands due to $(\mathrm{O}-\mathrm{H})$ and $(\mathrm{C}-\mathrm{H})$ stretching vibrations are observed in FT-IR spectra. The calculated values from PM3 method, of $v(\mathrm{O}-\mathrm{H})$ and $v(\mathrm{C}-$ $\mathrm{H})$ vibrations at 4838, 4805, 4041, 4021 and $4020 \mathrm{~cm}^{-1}$ can be assigned with the observe frequencies at $3905,3856,3753,3678$ and $3652 \mathrm{~cm}^{-1}$ respectively. The $v(\mathrm{O}-\mathrm{H})$ stretching vibrations is reported in the region $3580-3500 \mathrm{~cm}^{-1}$ in the literature [26-p260], whereas, the $v(\mathrm{C}-\mathrm{H})$ vibration is reported in the range $3100-3000 \mathrm{~cm}^{-1}$ in the literature [26-p226]. So these modes are found at higher values as reported earlier. An absorption band is observed in the FTIR spectra at $1585 \mathrm{~cm}^{-1}$ and it is calculated at $1586 \mathrm{~cm}^{-1}$ from Wilson GF matrix method with vibrational modes $v(\mathrm{C}-\mathrm{C}) \mathrm{R} 3[95 \%] \mathrm{PED}$, it is calculated at $1599 \mathrm{~cm}^{-1}$ with vibrations $v(\mathrm{C}-\mathrm{C}) \mathrm{R} 2$-symm and $\phi(\mathrm{C}-\mathrm{C}-\mathrm{C}) \mathrm{R} 2$ from semi-empirical PM3 method. A weak band is observed having two peaks observed at 1563 and $1508 \mathrm{~cm}^{-1} \&$ these are calculated at 1564 and $1510 \mathrm{~cm}^{-1}$ respectively with Wilson method, with vibrational modes $v(\mathrm{C}-\mathrm{C}) \mathrm{R} 1$ [98\%] and $v(\mathrm{C}-\mathrm{C}) \mathrm{R} 1[98 \%]$ in both cases. In the PM3 method only one peak in this band at frequency $1523 \mathrm{~cm}^{-1}$ is obtained, with $v(\mathrm{C}-\mathrm{C}) \mathrm{R} 4$-asymmetric stretch and in-plane bending of $\phi(\mathrm{O}=\mathrm{C}-\mathrm{O})$ adj- $\mathrm{R} 4$. This band is reported in the range $1515-1646 \mathrm{~cm}^{-1}$ by Ludwig et al $\mathrm{l}^{30}$, which is in good harmony. A highly intense absorption band, with two peaks one at $1482 \mathrm{~cm}^{-1}$ and other at $1437 \mathrm{~cm}^{-1}$ is obtained in the FTIR spectra, which are calculated in GF matrix method at $1485 \mathrm{~cm}^{-1}$ and $1434 \mathrm{~cm}^{-1}$ with modes of vibrations as $v(\mathrm{C}-\mathrm{C}) \mathrm{R} 2[70 \%], \mathrm{v}(\mathrm{C}$ $\mathrm{C}) \mathrm{R} 1[24 \%]$ and $v(\mathrm{C}-\mathrm{C}) \mathrm{R} 2[42 \%], v(\mathrm{C}-\mathrm{O})[24 \%], v(\mathrm{C}=\mathrm{O})[14 \%]$ for the second peak, respectively. In the PM3 method these absorption peaks are calculated at 1486 and $1431 \mathrm{~cm}^{-1}$ 
respectively, attributing to the symmetric stretching of $v(C-C) R 5$ and $v(C-C)$ adj-R5. The stretching mode $v(C-C)$ ring is reported in the frequency range, $1616-1455 \mathrm{~cm}^{-1}$ in the literature $^{24}$. In the FTIR spectra an absorption band with two peaks, one at $1326(\mathrm{msh})$ and the other at $1310(\mathrm{~s}) \mathrm{cm}^{-1}$, are observed and these are calculated from Wilson method at frequencies 1331 and $1310 \mathrm{~cm}^{-1}$ respectively, with modes of vibrations as $v(\mathrm{C}-\mathrm{C}) \mathrm{R} 2-\mathrm{O}[98 \%]$ and $\mathrm{v}(\mathrm{C}-$ C)R1[96\%] respectively. This band is calculated at 1319 and $1291 \mathrm{~cm}^{-1}$ from second method having vibrational modes as $v(\mathrm{C}-\mathrm{C}) \mathrm{R} 2$ asymmetric stretch, in-plane bending $\phi(\mathrm{C}-\mathrm{C}-\mathrm{C}) \mathrm{R} 2$ and $v(C-C) R 5$ asymmetric stretch, in-plane bending $\phi(C-C-C) R 5$, respectively.

An absorption band with peaks at 1270, 1224, 1185, 1175 and $1163 \mathrm{~cm}^{-1}$ are observed in the FTIR spectra, which are calculated from Wilson method at 1265, 1227, 1193, 1181 and $1164 \mathrm{~cm}^{-1}$ respectively with vibrational modes as $\mathrm{v}(\mathrm{C}-\mathrm{C}) \mathrm{R} 1-\mathrm{O}[59 \%]+\mathrm{v}(\mathrm{C}-\mathrm{O}) \operatorname{adj}-\mathrm{Sb}[14 \%]$, $v(\mathrm{C}-\mathrm{C}) \mathrm{R} 1-\mathrm{Sb}[90 \%], \quad v(\mathrm{C}-\mathrm{O}) \mathrm{R} 3-\mathrm{Sb}[86 \%], \quad v(\mathrm{C}-\mathrm{C}) \mathrm{R} 2[86 \%] \quad$ and $\quad \mathrm{v}(\mathrm{C}-\mathrm{C}) \mathrm{R} 3-\mathrm{Sb}[92 \%]$ respectively. From the PM3 method only three absorption peaks in this band region are found which are calculated at 1278,1223 and $1164 \mathrm{~cm}^{-1}$ with modes as $\mathrm{v}(\mathrm{C}-\mathrm{C}) \mathrm{R} 1$ asymmetric stretch + in-plane bending $\phi(C-C-C) R 1$, ring R1-breathing (or puckering) $+v(C-C) R 1$ asymmetric stretch. This band is reported in the range of 1110 to $1069 \mathrm{~cm}^{-1}$ in the literature $\mathrm{e}^{24}$.

A weak absorption band is observed containing four peaks found at 1097(w), 1021(w), 998(w) and 916(w) $\mathrm{cm}^{-1}$, these are calculated from Wilson GF matrix method, at 1092, 1024, 997 and $919 \mathrm{~cm}^{-1}$ with vibrational modes as $v(\mathrm{C}-\mathrm{C}) \mathrm{R} 1-\mathrm{O}[70 \%]+\phi(\mathrm{C}-\mathrm{C}-\mathrm{C}) \mathrm{R} 4[10 \%]$, $v(\mathrm{C}-\mathrm{C}) \mathrm{R} 1-\mathrm{Sb}[78 \%], v(\mathrm{C}-\mathrm{C}) \mathrm{R} 2-\mathrm{Sb}[73 \%]+\phi(\mathrm{C}-\mathrm{C}-\mathrm{C}) \mathrm{R} 3[10 \%]$ and $\mathrm{v}(\mathrm{C}-\mathrm{C}) \mathrm{R} 1-\mathrm{O}[67 \%]+$ $v(\mathrm{C}-\mathrm{O}) \mathrm{R} 1-\mathrm{O}[10 \%]$ respectively. This absorption band is calculated from PM3 method at only two peaks viz. $955 \& 908 \mathrm{~cm}^{-1}$ respectively, with modes of vibration as, rings R1\&R3 deformations and ring $\mathrm{R} 4$ breathing $+\mathrm{v}(\mathrm{C}-\mathrm{O})$ adj-R4 stretching.

A medium intense peak is observed at $864 \mathrm{~cm}^{-1}$ in the FTIR spectra and it is calculated at $866 \mathrm{~cm}^{-1}$ from Wilson method having vibrational modes as $\phi(\mathrm{C}-\mathrm{C}-\mathrm{C}) \mathrm{R} 3[85 \%] \& \phi(\mathrm{Sb}-\mathrm{C}-$ C)[10\%], whereas, from PM3 method it is calculated at $871 \mathrm{~cm}^{-1}$ with stretching mode $v(\mathrm{C}$ O)adj-R5. In the FTIR spectra a strong band is obtained comprising three absorption peaks at frequencies 690(s), 667(s) and $615(\mathrm{wsh}) \mathrm{cm}^{-1}$, this band is calculated from Wilson GF method at frequencies 695,665 and $621 \mathrm{~cm}^{-1}$ respectively, having modes of vibrations as $\tau(\mathrm{C}$ $\mathrm{C}) \mathrm{R} 1[62 \%]+\tau(\mathrm{C}-\mathrm{C}) \mathrm{R} 3[18 \%]+\tau(\mathrm{C}-\mathrm{C}) \mathrm{R} 2[17 \%], \omega(\mathrm{C}-\mathrm{O}) \mathrm{R} 4[64 \%]+\tau(\mathrm{C}-\mathrm{C}) \mathrm{R} 4[12 \%]$ and $\phi(\mathrm{C}-\mathrm{C}-\mathrm{C}) \mathrm{R} 2[56 \%]+\mathrm{v}(\mathrm{Sb}-\mathrm{C})[18 \%]+\mathrm{v}(\mathrm{C}-\mathrm{C}) \mathrm{R} 2[10 \%]$, respectively, whereas this band is calculated from PM3 method at frequency peaks 689,669 and $619 \mathrm{~cm}^{-1}$, attributing to the vibrational modes as ring R2-breathing, in-plane bending $\phi(\mathrm{C}-\mathrm{C}-\mathrm{C}) \mathrm{R} 2 \& \mathrm{R} 3$ and ring $\mathrm{R} 4-$ twisting. This band seems to be one of the characteristic modes of the title compound. In the lower part of the FTIR spectra a weak absorption band is obtained comprising three peaks observed at frequencies 581(w), 554(w) and $400(\mathrm{~m}) \mathrm{cm}^{-1}$, these are calculated from Wilson method at frequencies 571,559 and $393 \mathrm{~cm}^{-1}$ respectively, attributing to the vibrational modes as, $\phi(\mathrm{C}-\mathrm{C}-\mathrm{C}) \mathrm{R} 3[74 \%]+\phi(\mathrm{Sb}-\mathrm{C}-\mathrm{C})[10 \%], \phi(\mathrm{C}-\mathrm{C}-\mathrm{C}) \mathrm{R} 1[84 \%]$ and $\tau(\mathrm{C}-\mathrm{C}) \mathrm{R} 2[91 \%]$. From semi-empirical PM3 method, this band is calculated with absorption peaks at 580, 554 and $397 \mathrm{~cm}^{-1}$ respectively, with vibrational modes as ring R1-twisting $+\tau(\mathrm{C}-\mathrm{C}) \mathrm{R} 2,(\mathrm{O}=\mathrm{C}-\mathrm{O}) \mathrm{R} 5$ R5-rocking + in-plane bending $\phi(C-C=O)$, respectively. Torsional mode $\tau(\mathrm{C}-\mathrm{C}) \mathrm{R} 2[91 \%]$, also seems to be a characteristic mode of the title compound, and it is reported in the frequency range of $251-412 \mathrm{~cm}^{-1}$ in the literature ${ }^{30}$. 


\section{Conclusions}

Normal coordinate analysis data performed for the title compound from both Wilson G F matrix method and Semi-empirical PM3 method shows close resemblance of the calculated \& observed vibrational bands. The value of frequency difference for asymmetric and symmetric stretching $\Delta v$ for $v(\mathrm{CO} 2)_{\text {asym }}$ and $v(\mathrm{CO} 2)_{\mathrm{sym}}$ is calculated as $1638-1253=385 \mathrm{~cm}^{-1}$ from Table 2(a) and 2(c), which is greater than $300 \mathrm{~cm}^{-1}$, this suggests that the coordination number of antimony is five confirming the trigonal bipyramidal(TBPY) structure of the title compound. Further the high value of $\Delta v$ also indicates that the secondary bonding interactions between central antimony atom and carbonyl oxygen atoms is on weaker side for this molecule ${ }^{34}$.

\section{Acknowledgement}

The help received from Prof. V D Gupta, Emeritus Scientist and former Head, Department of Physics, Lucknow University Lucknow, for his meaningful suggestions is greatly acknowledged.

\section{References}

1. Misra R, Design, Synthesis, Structure, Antibacterial and Antitumour activity of Organo-Arsenic and Organo-Antimony derivates, $\mathrm{Ph}$. D Thesis, Lucknow University; 2006, 250-279.

2. Judwig C, Dolny M and Gotze H J, Spectrochimica Acta Part A. 2000, 56, 547-555.

3. Jensen K A and Nielsen H P, Infrared spectra of some organic compounds of group (VB) elements; Acta Chem. Scand, 1963, 17, 1875-1885.

4. Barucki H, Coles S J, Costello J F, Gelbrich T and Hursthouse M B, J Chem Soc., Dalton Trans, 2000, 2319-2325.

5. Stewart J J P, J. Comput Chem., 1989, 10, 209.

6. Stewart J J P, MOPAC 2007, Stewart Computational Chemistry, version, 7.075W.

7. Chandarshekhar K, Behl H M, Vishal K, Sidhu O P, Pushpangadan P, Rao C V, Shukla S K, Ranjan A, Kant R, Singhal K and Raj P, Triorganoantimony compounds for pesticidal use, PCT/IN2004/000407;WO/2006/067800.

8. Wilson E B Jr., Decius J C and Cross P C, Molecular Vibrations, Dover Publications, 1980, 11-31.

9. Urey H C and Bradley C A, Phys Rev., 38, 1969-1975.

10. The Royal society of Chemistry, CCDC no. 186/1998, 2000.

11. Shimanouchi $\mathrm{T}$, in Computer program for normal coordinate treatment of polyatomic molecules; University of Tokyo, 1968.

12. Srivastava S, Srivastava S, Singh S, Gupta V P and Gupta V D, Eur Polym J, 2002, 38(7) 1423-1434.

13. Gotze H J, Lemannczich P and Schaaf B, Spectrochimica Acta Part A, 1994, 50, 1871.

14. Scherer J R, Spectrochimica Acta, 1964, 20, 345.

15. Tasumi M, Urano T and Nakata M, J Mol Structure, 1986, 146, 383.

16. Lau C L and Snyder R G, Spectrochimica Acta Part A, 1971, 27, 2073.

17. Fogarasi G, Zhou X, Taylor P W and Pulay P, J Am Chem Soc, 1992, 114, 8191.

18. Pulay P, Fogarasi G, Pang F and Boggs J E, J Am Chem Soc., 1979, 101, 2550.

19 http://winmostar.com/index_en.html.

20. Misra N, Prasad O and Sinha L, Indian J Biochem Biophys., 2006, 43, 173-181. 
21. Singh P K, Hasan T, Prasad O, Sinha L, Raj K and Misra N, Spectroscopy, 2006, 20(5-6), 275-283.

22. Hasan T, Singh P K, Misra R, Raj P and Misra N, Pramana J Physics, 2007, 68(5), 875-881.

23. Hasan T, Singh P K, Singhal K, Raj P and Misra N, Pramana J Physics, 2007, 69(4), 675-680.

24. Colthup N B, Daly L H, Wiberley S E; Introdution to Infrared and Raman Spectroscopy; Academic Press; New York, 1964, p 74; Colthup N B, Daly L H, Wiberley S E; Introduction to Infrared and Raman Spectroscopy; Academic Press; New York, 1964, p 199, 212, 225, 249.

25. Jha N K, Sharma P and Ugal J R, Indian J Chem.,1993, 32(A), 74-77.

26. Biradar N S and Kulkarni V K, J. Inorgnucl Chem., 1971, 33, 3781.

27. Ruddick J N R and Sames J R, J. Organometal Chem., 1973, 60, 233.

28. Shankar D, Rai A K, Singh Y P, Rehwani H, Khushalani V and Gupta R S, Bioinorg Chem and Appl., 2006, 1-7.

29. Khosa M K, Mazhar M, Ali S, Shahid K and Malik F, Turk J Chem., 2006, 30, 345-354.

30. Ludwig C, Dolny M and Gotze H J, Spectrochim. Acta Part A, 1997, 53, 2363-2372.

31. Shobatake K, Postmus C, Ferraro J R and Nakamoto K, Appl Spectrosc, 1969, 23(1), 12.

32. Gotze H J, Lemannczick P and Schaaf B, Spectrochimica Part A, 1999, 50, 1871.

33. Whiffen D H, J. Chem, Soc, 1956, 1350.

34. Yu L, Ma Y Q, Wang G C and Li J S, Heteroatom Chemistry, 2004, 15, 32-36. 


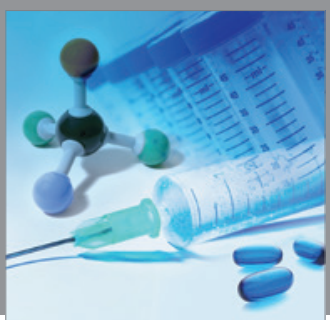

International Journal of

Medicinal Chemistry

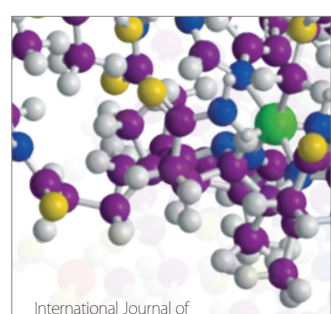

Carbohydrate Chemistry

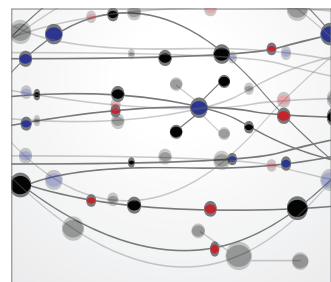

The Scientific World Journal
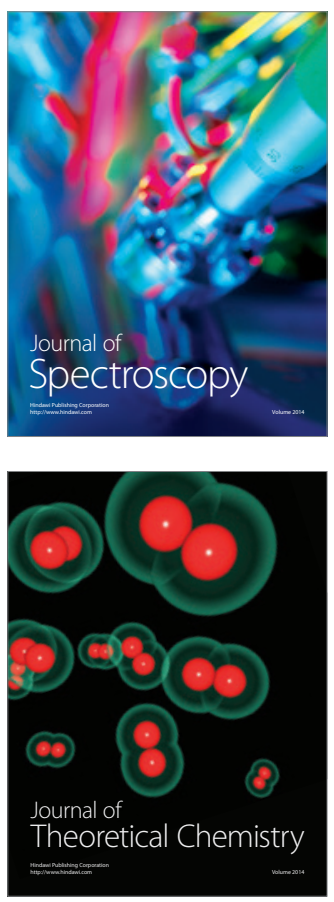
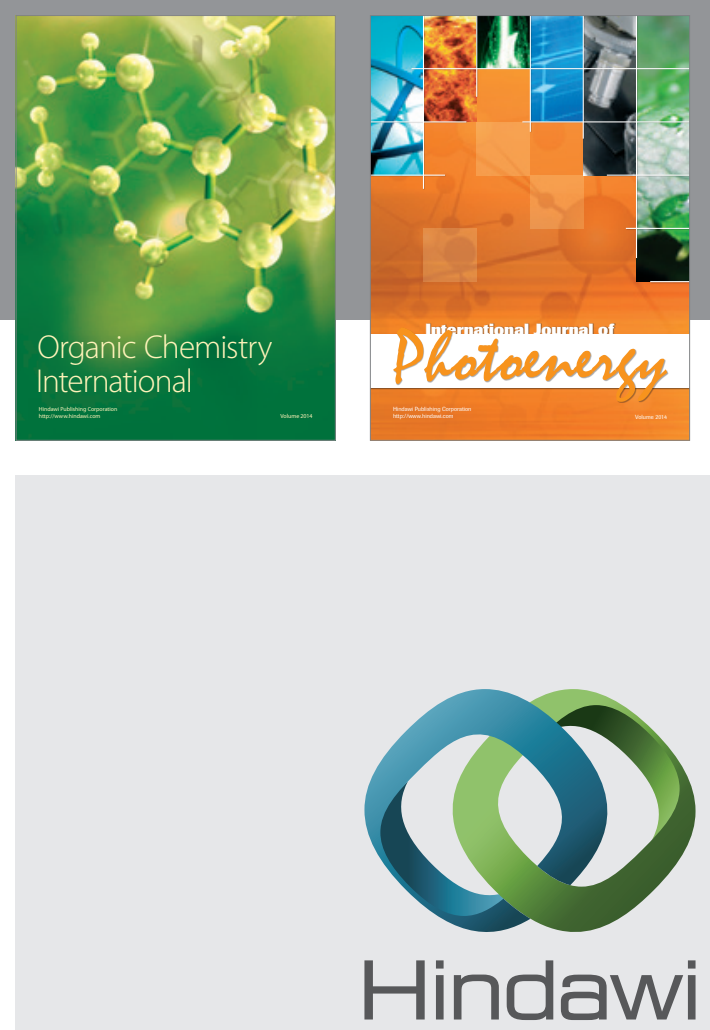

Submit your manuscripts at

http://www.hindawi.com
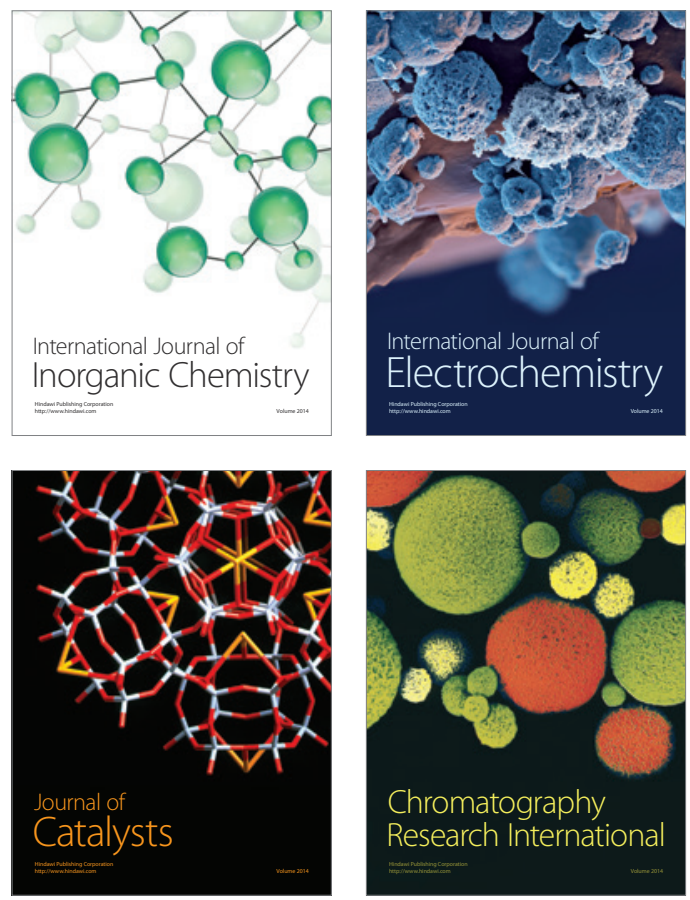
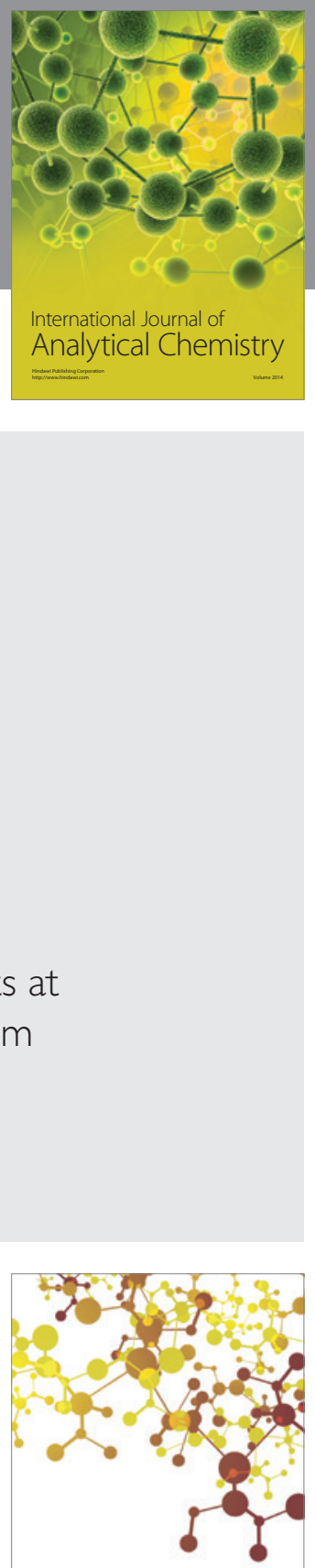

Journal of

Applied Chemistry
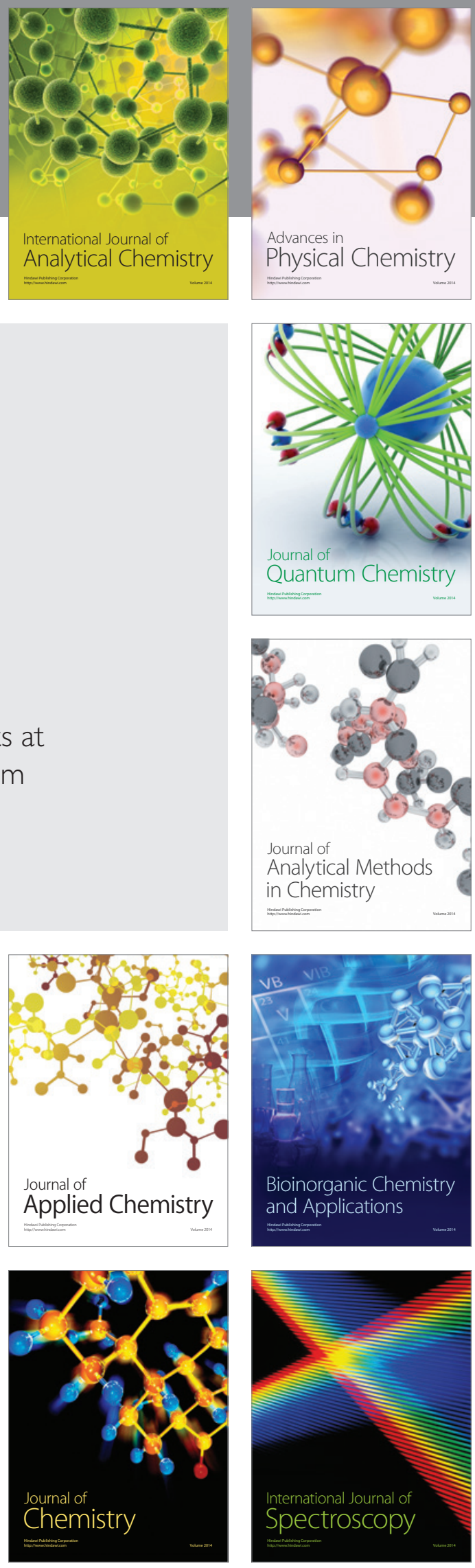